\title{
INL Bettis Water Treatment Project Report
}

\author{
R. L. Demmer \\ J. F. Berg \\ J. E. Fonnesbeck
}

June 2009

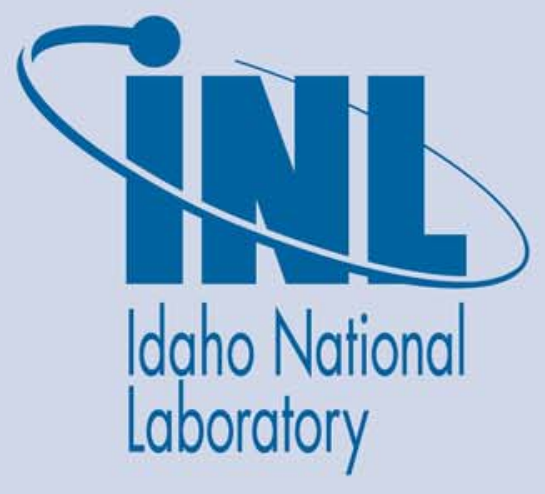




\title{
INL Bettis Water Treatment Project Report
}

\author{
R. L. Demmer \\ J. F. Berg \\ J. E. Fonnesbeck
}

June 2009

\section{Idaho National Laboratory \\ Idaho Falls, Idaho 83415}

\author{
Prepared for the \\ Bettis Atomic Power Laboratory \\ Bechtel Marine Propulsion Corporation \\ West Mifflin, PA \\ and for the \\ U.S. Department of Energy \\ Under DOE Idaho Operations Office \\ Contract DE-AC07-05ID14517
}




\begin{abstract}
Tests of a customer defined (Bechtel Marine Propulsion Corporation, West Mifflin, PA) plutonium water treatment system were conducted at the Idaho National Laboratory (INL). These tests were designed to give insight into how plutonium interacts with three readily available ion-exchange media. The solutions prepared during these tests were not homogeneous and probably consist of particulate and colloidal species as well as soluble species.

The overall results of these tests demonstrated that plutonium contamination from an oxide form dissolved or suspended in water, while a difficult problem, can be dealt with using the common media. Results from the "bench scale" $\mathrm{K}_{\mathrm{D}}$ and dynamic flow tests were very consistent and showed that the highest removal efficiency was achieved from the DT-30 (94\%) with the IRN150 next (89\%) and with the lowest efficiency with IRC-748 (57\%). The "pilot scale" tests showed that the IRN-150 (first column) had even higher efficiency with $>99 \%$ removal (virtually $100 \%$ ) in each of the 3 flow regimes; this was consistent with the results of the "bench scale" tests. The "pilot scale" tests also showed that the IRC-748 was less effective, but at $80 \%$ overall effectiveness, it was substantially higher than the "bench scale" tests.
\end{abstract}





\section{ACKNOWLEDGMENTS}

The authors would like to thank the many people who helped us prepare the ion exchange systems and perform some of the chemical analysis; principle among these individuals are Jeff Giglio, Steve Priebe, Simeon Thompson, Marcos Jimenez and James Sommers. We would also like to thank our customer Duane Humphreys and the staff at Bechtel Marine Propulsion Corporation for a challenging scope of work and support throughout the project. 



\section{CONTENTS}

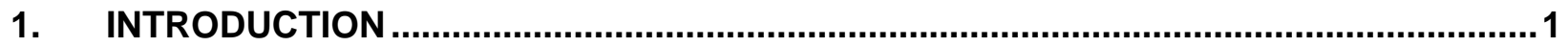

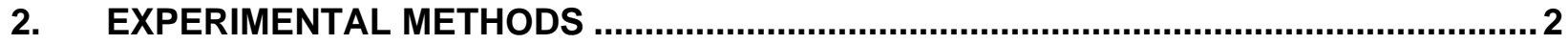

$2.1 \quad$ Laboratory Tests for Plutonium Oxidation State ............................................. 2

2.2 Investigation of Plutonium/Water Solutions .................................................... 6

2.3 X-ray Diffraction Analysis of Plutonium Oxide (Precipitate) in Water .............. 8

2.4 Small Scale (Bench Scale) Laboratory $K_{D}$ Tests........................................... 10

2.5 Pilot Scale Tests of Ion-Exchange Media ...................................................... 13






\section{ACRONYMS}

$\begin{array}{ll}\text { AL } & \text { Analytical Laboratory } \\ \text { DI } & \text { Distilled Water } \\ \text { DPM } & \text { Disintegrations per Minute } \\ \text { FCV } & \text { Free Column Volume } \\ \text { ICDD } & \text { International Centre of Diffraction Database } \\ \text { ICP-MS } & \text { Inductively Coupled Plasma Mass Spectrometer } \\ \text { INL } & \text { Idaho National Laboratory } \\ \text { IX } & \text { Ion-exchange } \\ \text { K } & \text { Distribution Coefficient } \\ \text { LSC } & \text { Liquid Scintillation Counting } \\ \text { MFC } & \text { Materials and Fuels Complex (a Laboratory Facility at the INL) } \\ \text { NBL } & \text { New Brunswick Laboratory } \\ \text { NIST } & \text { National Institutes of Standards and Technology } \\ \text { NRF } & \text { Naval Reactors Facility }\end{array}$




\section{INTRODUCTION}

As our industry moves towards cleanup and disposition of some of the legacy issues in the nuclear, defense and energy infrastructure, there are some problems that will be more difficult with which to deal. One such problem is that of potentially plutonium-contaminated materials that were stored in a water-filled storage basin at the Idaho National Laboratory (INL) Site.

A project was developed between the INL Battelle Energy Alliance Contractor and Bechtel Marine Propulsion Corporation to determine the expected character of the potential plutonium contamination and remediate the contaminated water. This has been a difficult problem, partly because of uncertainty in the chemical composition of the starting material and partly because of the tendency of plutonium to form many different species in water including "colloidal" species that give a heterogeneous solution.

Small containers of contaminated materials have been immersed in a water-filled storage basin. The $\mathrm{pH}$ of the water in the basin is approximately 6.2 due to the absorption of carbon dioxide from the atmosphere. Due to the possibility of deterioration of the gasket seals on the storage containers, water may have leaked into some of the containers. As a consequence, chemical reactions may have taken place within the storage containers which affect the chemistry of plutonium present within the containers. Possible chemical reactions which may have taken place are:

\section{Hydroxide Formation}

Barium, cesium, and strontium are present in the containers as either fission products or radioactive decay products. These elements will react with water present within the containers to form hydroxides, increasing the $\mathrm{pH}$ of the contents of the container. An increased $\mathrm{pH}$ would promote the formation of plutonium hydroxides and plutonium oxyhydroxides.

\section{Oxide Formation}

Metals (including plutonium) present in the containers will react with oxygen present within the containers to create metal oxides.

\section{Carbonic Acid formation}

Carbon dioxide present within the containers would dissolve in any free water that may be present and would react to create $\mathrm{H}_{2} \mathrm{CO}_{3}$. The formation of carbonic acid will lower the $\mathrm{pH}$ of the container contents. Lower $\mathrm{pH}$ would promote the formation of plutonium carbonate complexes and inhibit formation of plutonium hydroxides.

\section{Nitric Acid Formation}

Nitrogen and oxygen present within the containers would dissolve in any free water that may be present. Radiolysis of nitrogen and oxygen dissolved in water could create $\mathrm{HNO}_{3}$ by the following reaction: 


$$
2 \mathrm{~N}_{2}+5 \mathrm{O}_{2}+2 \mathrm{H}_{2} \mathrm{O} \rightarrow 4 \mathrm{HNO}_{3}
$$

The formation of nitric acid in solution will lower the $\mathrm{pH}$ of the container contents and would promote formation of plutonium nitrates (which are water soluble).

For purposes of this test program, the chemical form of the plutonium was assumed to be plutonium oxide.

The approach taken by the INL is to perform laboratory tests that determine the oxidation state, colloidal (heterogeneous solution) nature and determine which ion-exchange media will remove the plutonium from water at a near neutral $\mathrm{pH}$. All experiments were performed at the Materials and Fuels Complex (MFC) at the INL. The tests were designed to mimic the water chemistry reactions that we expect in a water-filled storage basin and form an integrated demonstration of the problem and potential solution, to show through first principles what we would expect and to demonstrate that with pilot scale tests. We accomplished this goal and thoroughly examined the plutonium/water system, determining that water cleanup goals could be accomplished with equipment available at the INL.

\section{EXPERIMENTAL METHODS}

\subsection{Laboratory Tests for Plutonium Oxidation State}

The determination of the plutonium oxidation states $(+3,+4 \&+6)$ in solution was to employ two anion exchange columns for separations. One column would be adjusted to the chloride form and the second to the nitrate form. Ultimately, this procedure was modified, and only the chloride form columns were required to accomplish the necessary separation. The ultimate priority, however, has been to ascertain the distribution of oxidation states of plutonium in $\mathrm{pH}$ of 6.2 as requested by our clients at Bettis.

The plutonium used for the experiments discussed in this section was obtained from a New Brunswick Laboratory (NBL) CRM-126 Pu standard solution. A dilution was made of the original standard, adjusted to $12,500 \mathrm{DPM} / \mathrm{mL}$ alpha activity, in $0.25 \underline{\mathrm{M}} \mathrm{HNO}_{3}$. This dilution will be referred to as the "Pu Standard dilution" from this point. The CRM-126 consists of 97.9 Wt. \% $\mathrm{Pu} 239,2.06 \mathrm{Wt} . \% \mathrm{Pu} 240$ and $0.0016 \mathrm{Wt}$. \% Pu 241. Liquid Scintillation Counting (LSC) was used for all data acquisition in all the experiments, which quantified the total alpha energy arising from both the $\mathrm{Pu} 239$ and 240 isotopes. The alpha energies at 5.156, 5.144, and 5.105 MeV for Pu 239 and 5.168 and 5.124 MeV for Pu 240 overlap; therefore, the resultant spectrum is a broad curve which must be integrated for total alpha activity. See Figure 1 below for a representative LSC Pu 239 and 240 alpha spectrum. The activity that appears in the low energy range of Figure 1, ie. $<20.8 \mathrm{KeV}$, represents the beta activity arising from the $\mathrm{Pu} 241$ present in the CRM-126. The $\mathrm{Pu} 241$ activity contribution was not used to quantify the $\mathrm{Pu}$ in this experiment. 


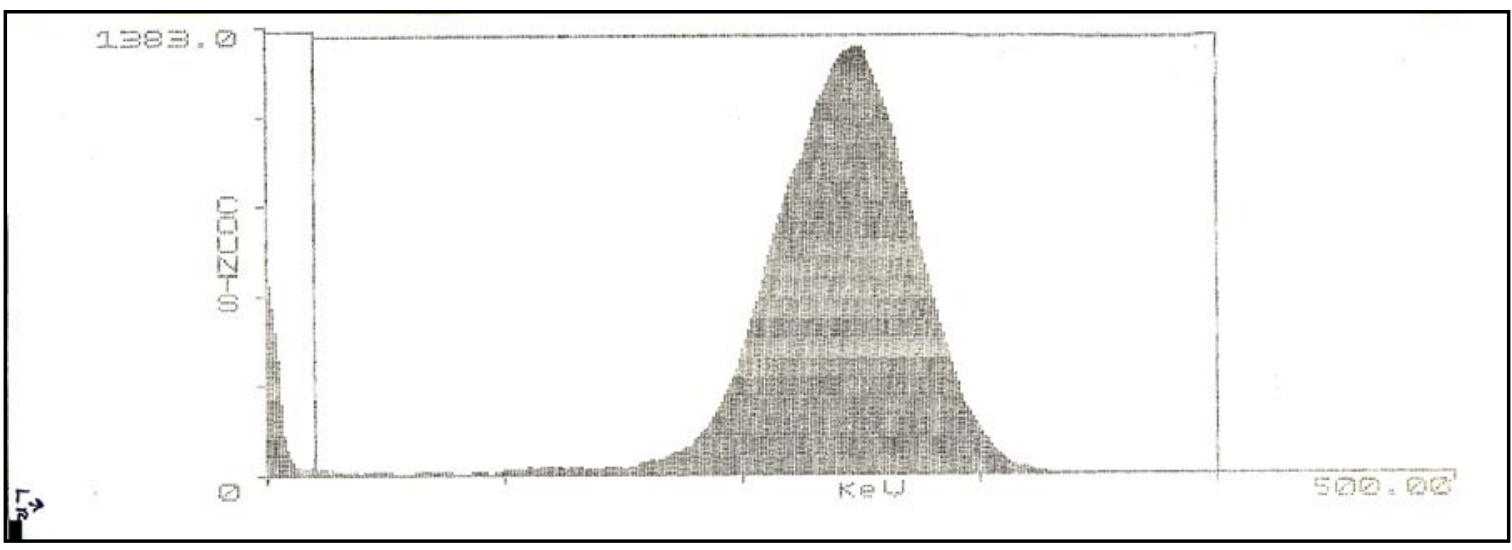

Figure 1. Liquid Scintillation Spectrum of the overlapping alpha energy peaks for $\mathrm{Pu} 239$ and $\mathrm{Pu} 240$ occuring between approximately 100 and $320 \mathrm{KeV}$. The lower counts shown below 20 $\mathrm{MeV}$ are the contributions from the beta emissions from $\mathrm{Pu} 241$.

Initial tests to determine the plutonium oxidation state followed the standard anion exchange methodology. This is actually a modification of a standard INL anion exchange method used for sequential separation of rare earth elements and all other $+1,+2$, and +3 elements from uranium and plutonium which are, in turn, separated from each other. Two $\mathrm{cc}$ of Bio-Rad ${ }^{\circledR}$ AG1-X2 (100-200 mesh) resin was placed in a Bio-Rad Poly-Prep column. The column was converted to the chloride form with $\sim 5 \mathrm{~mL}$ of $9 \underline{\mathrm{M}} \mathrm{HCl}$. Two $\mathrm{mL}$ of the Pu Standard was dried down and then re-dissolved in $9 \underline{\mathrm{M} \mathrm{HCl}}$, evaporated and dissolved in $1 \mathrm{~mL} 9 \mathrm{M} \mathrm{HCl}$. This was then loaded onto the prepared Bio-Rad column. An additional $9 \mathrm{~mL}$ of $9 \underline{\mathrm{M}} \mathrm{HCl}$ was then passed through the column and collected as a $10 \mathrm{~mL}$ elution fraction. This fraction should have contained any $\mathrm{Pu}^{+3}$ present in the solution. Next, the $\mathrm{Pu}^{+6}$ was collected in $5 \mathrm{~mL}$ fraction up to $20 \mathrm{~mL}$ total using $8 \underline{\mathrm{M}} \mathrm{HNO}_{3}$ as the eluent. $\mathrm{Pu}^{+6}$ has no retention to the resin in the $8 \underline{\mathrm{M}} \mathrm{HNO}_{3}$, but $\mathrm{Pu}^{+4}$ does and remains on the column. Finally, $0.3 \mathrm{M} \mathrm{HNO}_{3}$ was then used to remove any $\mathrm{Pu}^{+4}$ from the column, and this was collected in four $5 \mathrm{~mL}$ fractions.

A total of $\sim 25,000$ DPM of Pu activity was passed through the column. To quantify the activity eluted, $1 \mathrm{~mL}$ of each elution was placed in $20 \mathrm{~mL}$ liquid scintillation vials and mixed with $19 \mathrm{~mL}$ Optima Gold ${ }^{\circledR}$ scintillation cocktail. The total alpha activity was counted for each vial. One $\mathrm{mL}$ of the Pu Standard resulted in 12,450 DPM. This value, multiplied by 2 (24,900 DPM), was used to determine recoveries for each total eluent collected. From Table 1, the total activity recovered was, 24,684 DPM. Therefore, the percent recovery of Pu from this process was $99.1 \%$ which is essentially quantitative.

The three Pu oxidation states found in each eluent, including the small amount that remained on the resin, are shown below from the highest to lowest percent found from the above experiment:

$$
\mathrm{Pu}+3(63.8 \%)>\mathrm{Pu}+4(30.9 \%)>\mathrm{Pu}+6(3.6 \%)>>\mathrm{Pu}+? \text { in } \operatorname{Resin}(0.82 \%)
$$


Not only is $\mathrm{Pu}+3$ unretained on the column in $9 \mathrm{M} \mathrm{HCl}, \mathrm{Am}-241$, produced from $\mathrm{Pu}-241$ beta decay, is also unretained. However, in this case, the Am-241 alpha contribution to the LSC spectrum would be negligible.

Table 1. Elution Characteristics of CRM-126 Pu Standard Dilution From 9M HCl Loading.

\begin{tabular}{|c|c|c|c|c|c|c|c|c|}
\hline $\begin{array}{l}\text { Fraction } \\
\text { Collected }\end{array}$ & Eluent & $\begin{array}{l}\mathrm{Pu}^{+x} \\
\text { State }\end{array}$ & $\begin{array}{l}\text { Eluent } \\
\text { Fraction } \\
(\mathrm{mL})\end{array}$ & $\begin{array}{c}\text { LSC } \\
\text { Activity } \\
\text { Counted } \\
(\mathrm{DPM} / \mathrm{ml})^{*}\end{array}$ & $\begin{array}{c}\text { Total } \\
\text { Activity } \\
\text { Per } \\
\text { Fraction* }\end{array}$ & $\begin{array}{c}2 \text { Sigma } \\
( \pm \%)\end{array}$ & $\begin{array}{l}\text { Activity } \\
\text { Per Eluent } \\
\text { Total* }\end{array}$ & $\begin{array}{c}\% \\
\text { Recovery } \\
\text { Pu in } \\
\text { Each } \\
\text { Fraction }\end{array}$ \\
\hline 1 & $9 \mathrm{M} \mathrm{HCl}$ & +3 & $1-10$ & $1,589 \times 10$ & 15,890 & 0.66 & 15,890 & 63.8 \\
\hline 1 & \multirow{4}{*}{$8 \underline{\mathrm{M}} \mathrm{HNO}_{3}$} & \multirow{4}{*}{+6} & $1-5$ & $142 \times 5$ & 710 & 2.50 & \multirow{4}{*}{885} & \multirow{4}{*}{3.6} \\
\hline 2 & & & $6-10$ & $5 \times 5$ & 25 & 36.86 & & \\
\hline 3 & & & $11-15$ & $8 \times 5$ & 40 & 24.78 & & \\
\hline 4 & & & $16-20$ & $22 \times 5$ & 110 & 9.78 & & \\
\hline 1 & \multirow{4}{*}{$0.3 \underline{\mathrm{M}} \mathrm{HNO}_{3}$} & \multirow{4}{*}{+4} & $1-5$ & $653 \times 5$ & 3265 & 1.05 & \multirow{4}{*}{7,705} & \multirow{4}{*}{30.9} \\
\hline 2 & & & $6-10$ & $738 \times 5$ & 3690 & 0.98 & & \\
\hline 3 & & & $11-15$ & $120 \times 5$ & 600 & 2.77 & & \\
\hline 4 & & & $16-20$ & $30 \times 5$ & 150 & 7.46 & & \\
\hline 1 & Resin & NA & NA & $204 \times 1$ & 204 & 2.00 & 204 & 0.82 \\
\hline \multicolumn{7}{|c|}{ Total Recovered Activity } & 24,684 & \\
\hline \multicolumn{7}{|c|}{ Total Percent Recovery for Pu Sample Column Loading in $\mathrm{pH} 4$} & & 99.1 \\
\hline
\end{tabular}

Counted activity of the Pu Standard was 24,900 DPM.

*DPM: Disintegrations Per Minute, (alpha activity).

A second method, different than the standard method, was also employed to determine the oxidation state. In this method two columns were prepared in the same manner as is described previously; however, two $2 \mathrm{~mL}$ aliquots of the $\mathrm{Pu}$ standard were adjusted to $\mathrm{pH} 4$ and 6.2 respectively and allowed to equilibrate for oxidation state over a period of approximately 16 hrs. The matrices of the two solutions were adjusted to $9 \mathrm{M} \mathrm{HCl}$ only just prior to loading them onto the columns. One column was loaded with the $\mathrm{pH} 4$ pre-adjusted solution and the other column, with the $6.2 \mathrm{pH}$ pre-adjusted solution. Tables 2 and 3 show the results. There is a significant variation in the activity per fraction noted on these tables. These can be related to both the $\mathrm{pH}$ (changes in $\mathrm{pH}$ give different fraction activities) and in the portion of the fraction eluted (the amount of activity was generally lower with later fractions in the same series).

The total percent recovery for the $\mathrm{pH} 4$ loading was $99 \%$. The $\mathrm{Pu}$ found in each eluent including that which remained on the resin is listed below in decreasing percent order:

$$
\mathrm{Pu}+4(61.43 \%)>\mathrm{Pu}+3(33.2 \%)>\mathrm{Pu}+6(3.42 \%)>>\mathrm{Pu}+? \text { in } \operatorname{Resin}(0.96 \%)
$$

The total percent recovery for the $\mathrm{pH} 6.2$ loading was $100.4 \%$. The $\mathrm{Pu}$ found in each eluent including that which remained on the resin is listed below in decreasing percent order:

$$
\mathrm{Pu}+4(51.41 \%)>\mathrm{Pu}+3(44.5 \%)>\mathrm{Pu}+6(3.72 \%)>>\mathrm{Pu}(+?) \text { in } \operatorname{Resin}(0.77 \%)
$$


Table 2. pH 4 Pu Solution Loading.

\begin{tabular}{|c|c|c|c|c|c|c|c|c|}
\hline $\begin{array}{l}\text { Fraction } \\
\text { Collected }\end{array}$ & Eluent & $\begin{array}{l}\mathrm{Pu}^{+\mathrm{x}} \\
\text { State }\end{array}$ & $\begin{array}{l}\text { Eluent } \\
\text { Fraction } \\
(\mathrm{mL})\end{array}$ & $\begin{array}{c}\text { LSC } \\
\text { Activity } \\
\text { Counted } \\
(\mathrm{DPM} / \mathrm{ml})^{*}\end{array}$ & $\begin{array}{c}\text { Total } \\
\text { Activity } \\
\text { Per } \\
\text { Fraction* }\end{array}$ & $\begin{array}{c}2 \text { Sigma } \\
( \pm \%)\end{array}$ & $\begin{array}{l}\text { Activity } \\
\text { Per Eluent } \\
\text { Total* }\end{array}$ & $\begin{array}{c}\% \\
\text { Recovery } \\
\text { Pu in } \\
\text { Each } \\
\text { Fraction }\end{array}$ \\
\hline $\begin{array}{l}1 \\
2\end{array}$ & $9 \underline{\mathrm{M}} \mathrm{HCl}$ & +3 & $\begin{array}{c}1-5 \\
6-10\end{array}$ & $\begin{array}{c}1,277 \times 5 \\
367 \times 5\end{array}$ & $\begin{array}{l}6,383 \\
1,836\end{array}$ & $\begin{array}{l}0.74 \\
1.43\end{array}$ & 8,219 & 33.2 \\
\hline $\begin{array}{l}1 \\
2 \\
3 \\
4\end{array}$ & $8 \underline{\mathrm{M}} \mathrm{HNO}_{3}$ & +6 & $\begin{array}{c}1-5 \\
6-10 \\
11-15 \\
16-20\end{array}$ & $\begin{array}{c}139 \times 5 \\
4 \times 5 \\
5 \times 5 \\
21 \times 5\end{array}$ & $\begin{array}{c}697 \\
21 \\
24 \\
106\end{array}$ & $\begin{array}{c}2.54 \\
44.97 \\
39.25 \\
10.12\end{array}$ & 848 & 3.42 \\
\hline $\begin{array}{l}1 \\
2 \\
3 \\
4\end{array}$ & $0.3 \underline{\mathrm{M}} \mathrm{HNO}_{3}$ & +4 & $\begin{array}{c}1-5 \\
6-10 \\
11-15 \\
16-20\end{array}$ & $\begin{array}{c}1,836 \times 5 \\
1,002 \times 5 \\
158 \times 5 \\
50 \times 5\end{array}$ & $\begin{array}{c}9,179 \\
5,010 \\
790 \\
249\end{array}$ & $\begin{array}{l}0.61 \\
0.84 \\
2.35 \\
5.14\end{array}$ & 15,228 & 61.43 \\
\hline 1 & Resin & NA & NA & $239 \times 1$ & 239 & 1.83 & 239 & 0.96 \\
\hline \multicolumn{7}{|c|}{ Total Recovered Activity } & 24,534 & \\
\hline
\end{tabular}

Counted activity of the Pu Standard was 24,790 DPM.

*DPM: Disintegrations Per Minute (alpha activity) of one $\mathrm{mL}$ of the collected fraction.

Table 3. pH 6.2 Pu Solution Loading.

\begin{tabular}{|c|c|c|c|c|c|c|c|c|}
\hline $\begin{array}{l}\text { Fraction } \\
\text { Collected }\end{array}$ & Eluent & $\begin{array}{l}\mathrm{Pu}^{+\mathrm{x}} \\
\text { State }\end{array}$ & $\begin{array}{l}\text { Eluent } \\
\text { Fraction } \\
(\mathrm{mL})\end{array}$ & $\begin{array}{c}\text { LSC } \\
\text { Activity } \\
\text { Counted } \\
(\mathrm{DPM} / \mathrm{ml})^{*}\end{array}$ & $\begin{array}{c}\text { Total } \\
\text { Activity } \\
\text { Per } \\
\text { Fraction* }\end{array}$ & $\begin{array}{c}2 \text { Sigma } \\
( \pm \%)\end{array}$ & $\begin{array}{l}\text { Activity } \\
\text { Per Eluent } \\
\text { Total* }\end{array}$ & $\begin{array}{c}\% \\
\text { Recovery } \\
\mathrm{Pu} \text { in } \\
\text { Each } \\
\text { Fraction }\end{array}$ \\
\hline $\begin{array}{l}1 \\
2\end{array}$ & $9 \underline{\mathrm{M}} \mathrm{HCl}$ & +3 & $\begin{array}{c}1-5 \\
6-10\end{array}$ & $\begin{array}{c}1,839 \times 5 \\
365 \times 5\end{array}$ & $\begin{array}{l}9,196 \\
1,826\end{array}$ & $\begin{array}{l}0.61 \\
1.44\end{array}$ & 11,022 & 44.5 \\
\hline $\begin{array}{l}1 \\
2 \\
3 \\
4\end{array}$ & $8 \underline{\mathrm{M}} \mathrm{HNO}_{3}$ & +6 & $\begin{array}{c}1-5 \\
6-10 \\
11-15 \\
16-20\end{array}$ & $\begin{array}{c}142 \times 5 \\
5 \times 5 \\
8 \times 5 \\
29 \times 5\end{array}$ & $\begin{array}{c}712 \\
25 \\
41 \\
145\end{array}$ & $\begin{array}{c}2.50 \\
38.36 \\
23.90 \\
7.80\end{array}$ & 923 & 3.72 \\
\hline $\begin{array}{l}1 \\
2 \\
3 \\
4\end{array}$ & $0.3 \underline{\mathrm{M}} \mathrm{HNO}_{3}$ & +4 & $\begin{array}{c}1-5 \\
6-10 \\
11-15 \\
16-20\end{array}$ & $\begin{array}{c}1,916 \times 5 \\
517 \times 5 \\
82 \times 5 \\
34 \times 5\end{array}$ & $\begin{array}{c}9,582 \\
2,583 \\
408 \\
170\end{array}$ & $\begin{array}{l}0.60 \\
1.19 \\
3.60 \\
6.87\end{array}$ & 12,743 & 51.41 \\
\hline 1 & Resin & NA & NA & $192 \times 1$ & 192 & 2.08 & 192 & 0.77 \\
\hline \multicolumn{7}{|c|}{ Total Recovered Activity } & 24,880 & \\
\hline
\end{tabular}

Counted activity of the Pu Standard was 24,790 DPM.

*DPM: Disintegrations Per Minute. Activity of Alpha.

From the experiments conducted above, it can be seen that the initial $\mathrm{pH}$ of the $\mathrm{Pu}$ sample that is introduced to the anion exchange column has an effect on the oxidation state of the plutonium that is eluted and collected from the column. The only change in separation parameters was the initial $\mathrm{pH}$ of the loading solution as well as its matrix. Table 4 shows the percent of which oxidation state of plutonium was removed from the column corresponding with the eluent used. 
Table 4, Overall Plutonium Recovery By pH

\begin{tabular}{|c|c|c|c|}
\hline \multirow{2}{*}{ Eluent $/ \mathrm{Pu}^{+\mathrm{x}}$} & \multicolumn{3}{|c|}{ Percent $\% \mathrm{Pu}^{+\mathrm{x}}$ in Elution Fractions } \\
\cline { 2 - 4 } & $\mathrm{pH}-0.95$ & $\mathrm{pH} 4$ & $\mathrm{pH} 6.2$ \\
\hline$\underline{\mathrm{M} \mathrm{HCl}} / \mathrm{Pu}+3$ & 63.8 & 33.2 & 44.5 \\
$8 \mathrm{M} \mathrm{HNO}_{3} / \mathrm{Pu}+4$ & 30.9 & 61.4 & 51.4 \\
$0.3 \underline{\mathrm{M} \mathrm{HNO}} / \mathrm{Pu}+6$ & 3.6 & 3.42 & 3.7 \\
Resin & 0.82 & 0.96 & 0.77 \\
\hline
\end{tabular}

The total recovery of plutonium from all three processes was greater than $99 \%$, leaving less that $1 \%$ of that which was retained on the columns.

\subsection{Investigation of Plutonium/Water Solutions}

In order to best simulate the potential plutonium contamination conditions in the water-filled storage basins at INL, we prepared two surrogate samples of plutonium oxide $\left(\mathrm{PuO}_{2}\right)$ mixed in deionized (DI) water on 3/26/09. The weights are recorded in Table 5. The $\mathrm{PuO}_{2}$ used in these tests was a mixed oxide (containing about 14\% uranium) material that was on hand at the INL laboratory. It is different both in form and in isotopic distribution that the CRM-126 solution, that solution being essentially pure both in isotopic and elemental distribution, but unavailable in the form (solid) and quantity desired. Several grams of the $\mathrm{PuO}_{2}$ was obtained for use in this project.

Table 5, Plutonium Oxide Water Surrogate Data

\begin{tabular}{|c|c|c|}
\hline SAMPLE ID & PuO $_{\mathbf{2}}$ WEIGHT & DI WATER VOLUME \\
\hline $\mathrm{PuO}_{2} \# 1$ & $31.4 \mathrm{mg}$ & $100 \mathrm{~mL}$ \\
\hline $\mathrm{PuO}_{2} \# 2$ & $421.4 \mathrm{mg}$ & $50 \mathrm{~mL}$ \\
\hline
\end{tabular}

$\mathrm{PuO}_{2} \# 1$ and $\mathrm{PuO}_{2} \# 2$ were removed from the alpha glovebox. The solid oxide was allowed to settle at the bottom of the poly bottles and on 4/7/09, after 12 days of $\mathrm{PuO}_{2}$ contact with DI water, aliquots of these samples were taken to characterize this material for elemental and isotopic information using Inductively Coupled Plasma-Mass Spectrometry (ICP-MS). The results were difficult to obtain because of difficulty obtaining a steady state MS signal. However, some fundamental results were obtained. The total elemental concentration of the solutions showed them to consist both of plutonium and uranium. The total concentration of both was found to be approximately $4 \mu \mathrm{g} / \mathrm{mL}$ of solution. Of this total material, about $85 \%$ was plutonium of which $90 \%$ was as the ${ }^{239} \mathrm{Pu}$ isotope. The remaining fifteen percent of the total material was ${ }^{235} \mathrm{U}$. These are not absolute values due to the fact that the resultant ICP-MS signal was not stable, indicating that these elements were present as solid (colloidal?) suspensions in solution rather than solubilized ions which would result in homogeneous mixtures (very difficult to quantify using ICP-MS).

To characterize the plutonium concentration via its ${ }^{239} \mathrm{Pu}$ alpha activity, both unfiltered and filtered portions of both sample solutions were obtained. To filter, approximately $10 \mathrm{~mL}$ of the 
DI water for both $\mathrm{PuO}_{2} \# 1$ and \#2 were passed through a $0.45 \mu \mathrm{m}$ polypropylene filter cartridge to remove fine particulates suspended in them. Both unfiltered and filtered samples of $\mathrm{PuO}_{2} \# 1$ and \#2 were mixed immediately prior to taking $0.100 \mathrm{~mL}$ aliquots for liquid scintillation counting (LSC) to determine the plutonium alpha activity. The LSC results for the plutonium alpha activity are shown in Table 6 . Table 6 does not directly compare to Table 5 , partly due to the solubility effect (adding more $\mathrm{PuO}_{2}$ to the mixture does not necessarily increase the concentration of plutonium) and the overall instability of these solutions (which is underscored by the comparison of Tables 6,7 and 8 ).

Table 6, Plutonium Oxide Alpha Activity (7APR09)

\begin{tabular}{|c|c|c|}
\hline SAMPLE & $\begin{array}{c}\text { ALPHA ACTIVITY } \\
\text { (DPM/mL) }\end{array}$ & REMARKS \\
\hline $\mathrm{PuO}_{2} \# 1$ & $8.8 \mathrm{E}+6$ & unfiltered \\
\hline $\mathrm{PuO}_{2} \# 1 \mathrm{~F}$ & $1.9 \mathrm{E}+6$ & filtered \\
\hline $\mathrm{PuO}_{2} \# 2$ & $1.0 \mathrm{E}+7$ & unfiltered \\
\hline $\mathrm{PuO}_{2} \# 2 \mathrm{~F}$ & $8.1 \mathrm{E}+6$ & filtered \\
\hline
\end{tabular}

A serial dilution of filtered sample $\mathrm{PuO}_{2} \# 1 \mathrm{~F}$ was prepared on 7Apr09, in deionized water to approximate the target plutonium $\left({ }^{239} \mathrm{Pu}\right)$ concentration of $1.7 \mathrm{E}-6 \mathrm{~g} / \mathrm{L}$, or a measured alpha activity of $\sim 240 \mathrm{DPM} / \mathrm{mL}$. The measured $\mathrm{pH}$ of this $\mathrm{Pu}$ tracer solution was 7.4 , and a few drops of $2 \underline{\mathrm{M} \mathrm{HCl}}$ and $0.1 \underline{\mathrm{M} \mathrm{HCl}}$ were added to adjust the $\mathrm{pH}$ to 6.2 . A $5.00 \mathrm{~mL}$ aliquot of this $\mathrm{Pu}$ tracer solution was counted by LSC to determine the alpha activity, and found to be 0.4 $\mathrm{DPM} / \mathrm{mL}$. This activity was a factor of 600 lower than the expected dilution activity. At this point the previous suspicion that the filtered $\mathrm{PuO}_{2}$ solutions were not homogeneous was, for the most part, satisfied. This information also revealed that obtaining a representative sample for the plutonium activity would be very difficult. Additional samples of both unfiltered and filtered $\mathrm{PuO}_{2}$ solutions were obtained on 13Apr09 to determine the alpha activity by LSC. All samples were obtained unmixed, after standing since 7Apr09. The LSC alpha activity and variation from initial characterization on 7Apr09 are shown in Tables 7 and 8; note that the recovery is calculated in the last column, comparing the initial results (Table 6), to the measurements obtained upon standing (Tables 7 and 8).

Table 7, Plutonium Oxide Alpha Activity (13APR09)

\begin{tabular}{|c|c|c|}
\hline SAMPLE & $\begin{array}{c}\text { ALPHA ACTIVITY } \\
\text { (DPM/mL) }\end{array}$ & $\begin{array}{c}\text { RECOVERY } \\
\text { (from 7APR09) }\end{array}$ \\
\hline $\mathrm{PuO}_{2} \# 1$ & $1.7 \mathrm{E}+4$ & $0.2 \%$ \\
\hline $\mathrm{PuO}_{2} \# 1 \mathrm{~F}$ & $1.0 \mathrm{E}+5$ & $5.3 \%$ \\
\hline $\mathrm{PuO}_{2} \# 2$ & $2.5 \mathrm{E}+5$ & $2.5 \%$ \\
\hline $\mathrm{PuO}_{2} \# 2 \mathrm{~F}$ & $5.8 \mathrm{E}+6$ & $72 \% *$ \\
\hline
\end{tabular}

* Because of low sample volume, pipet tip touched the bottom of sample bottle.

From the results of the LSC activity on 13Apr09, samples from PuO2 \#1 and \#1F were obtained for verification. The first two samples were unmixed, and the second two samples were filtered through a $0.45 \mu \mathrm{m}$ polypropylene filter cartridge to provide additional 
clarification of the sample solutions. The results of the LSC alpha activity and comparison to the initial LSC alpha activity on 7Apr09 are shown in the following table.

Table 8, Plutonium Oxide Alpha Activity (14APR09)

\begin{tabular}{|c|c|c|c|}
\hline SAMPLE & $\begin{array}{c}\text { ALPHA ACTIVITY } \\
\text { (DPM/mL) }\end{array}$ & $\begin{array}{c}\text { RECOVERY } \\
\text { (from 7APR09) }\end{array}$ & REMARKS \\
\hline $\mathrm{PuO}_{2} \# 1$ & $2.2 \mathrm{E}+3$ & $0.025 \%$ & neat \\
\hline $\mathrm{PuO}_{2} \# 1 \mathrm{~F}$ & $1.8 \mathrm{E}+4$ & $0.95 \%$ & neat \\
\hline $\mathrm{PuO}_{2} \# 1 \mathrm{~A}$ & $2.7 \mathrm{E}+5$ & $3.1 \%$ & filtered \\
\hline $\mathrm{PuO}_{2} \# 1 \mathrm{~F} \mathrm{~A}$ & $2.1 \mathrm{E}+3$ & $0.11 \%$ & filtered \\
\hline
\end{tabular}

These results from 14Apr09, show a 100 fold increase in the filtered $\mathrm{PuO}_{2} \# 1$ sample, along with $\sim 9$ fold decrease in the filtered $\mathrm{PuO}_{2} \# 1 \mathrm{~F}$ sample. The inability to accurately characterize the plutonium alpha activity in these $\mathrm{PuO}_{2}$ samples makes them unsuitable for use in an experiment that will depend upon this known activity for the validation of selected media. Though a soluble plutonium standard (CRM-126) would be far better for consistent results during the pilot scale study, the desire of the Bettis customer is that the heterogeneous solution be used.

\subsection{X-ray Diffraction Analysis of Plutonium Oxide (Precipitate) in Water}

X-ray diffraction (XRD) analysis of the plutonium oxide in water solids left after removal of the supernate was performed. The precipitate material was collected on a glass filter from a neutral water solution and dried in air the alpha glovebox of the Analytical Laboratory (AL) at MFC. The brown precipitate was then scraped from the filter media onto a quartz, zerobackground XRD sample holder and adhered to with vacuum grease. A lanthanum hexaboride powder (SRM 660) was also sprinkled onto the sample holder for instrument alignment. The holder was then loaded into the XRD confinement chamber to prevent the possible spread of contamination. The chamber was then mounted onto the Scintag X1 diffractometer for analysis.

The plot below shows the obtained x-ray pattern and the instrumental analysis conditions. The pattern shows two phases, the NIST standard lanthanum hexaboride and a good match to plutonium oxide. These phases are identified by matching the International Centre for Diffraction Database (ICDD) files also shown on the plot below. No other phases were identified and if any other phases are present, they are at concentrations at or below the detection limit of the instrument.

Closer inspection of the diffraction peaks (Figure 3), particularly at the higher two theta scan region, shows that the main oxide peaks are shifted to the left with possible peak splitting. (The plot is denoted in terms of the angle of diffraction from the sample, the angle between the direction of the incident and diffracted x-ray beams, expressed as "degrees two theta.") This may indicate a mixed oxide structure, possibly due to the presence of uranium. Thus the pattern would indicate peak shifting or splitting to lower two theta values due to a mixture of 
plutonium and uranium oxide. Chemical analysis (ICP-MS, subsequent to the XRD) confirmed the presence of uranium oxide present in the plutonium oxide (about 14\%).

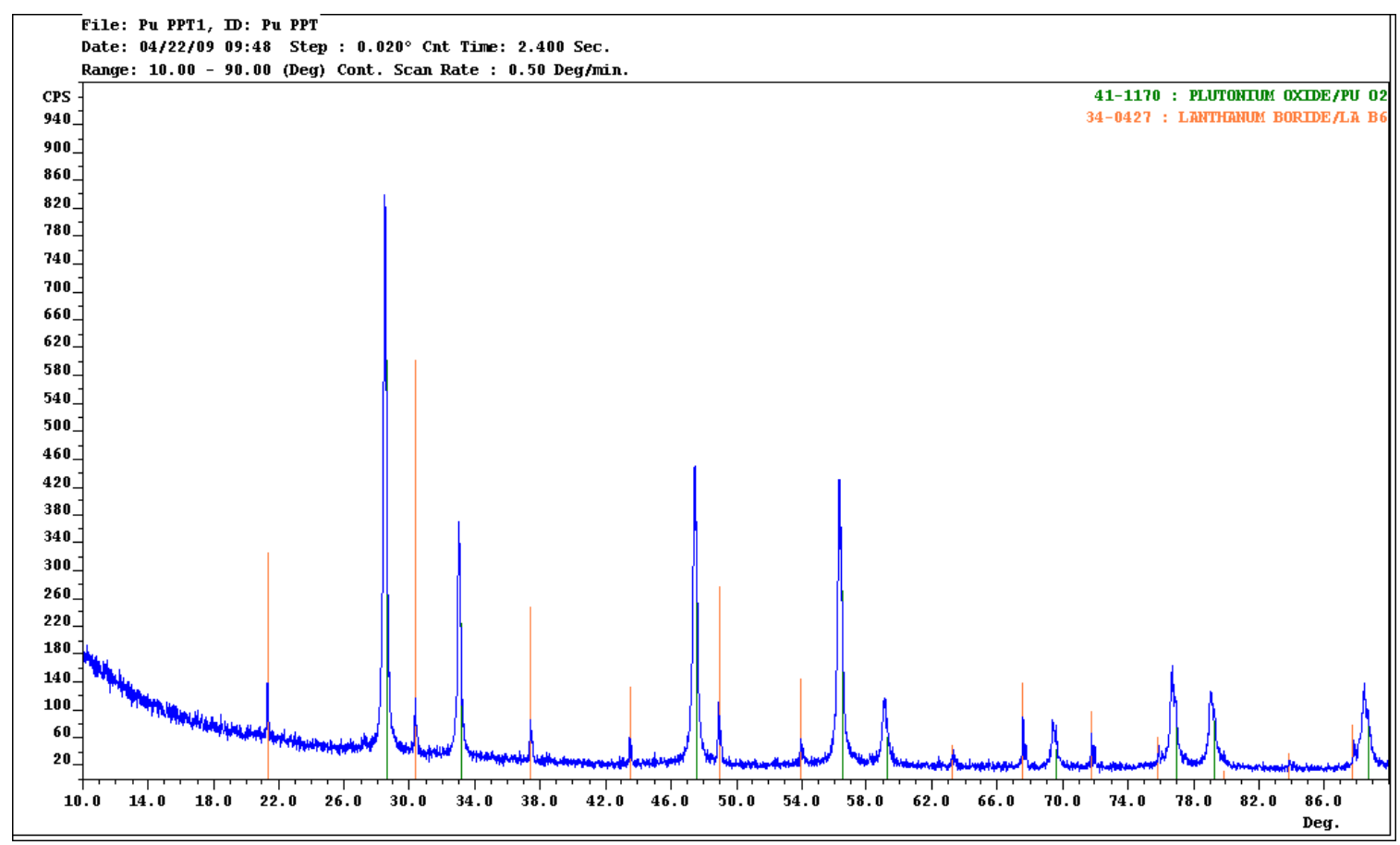

Figure 2, XRD Pattern of Plutonium Residue From Water Mixture.

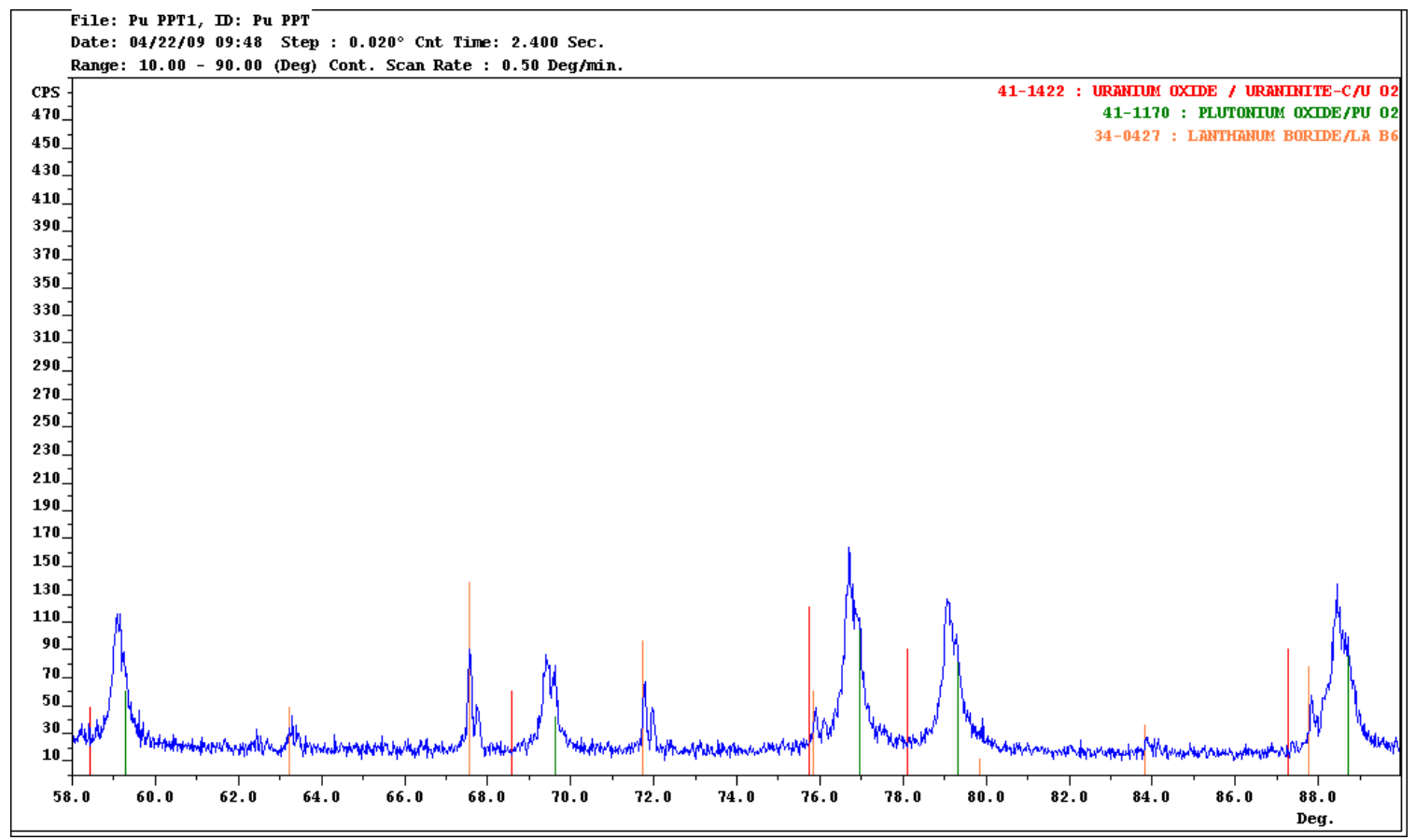

Figure 3, XRD Data With Emphasis on Higher Regions 


\subsection{Small Scale (Bench Scale) Laboratory $K_{D}$ Tests}

The three selected media, IRN-150, DT-30 and IRC-748 were tested to evaluate the decontamination factor (DF) and dynamic distribution coefficient $\left(\mathrm{K}_{\mathrm{D}}\right)$ for trace levels of plutonium at a $\mathrm{pH}$ of 6.2. These were small scale laboratory tests that used $\sim 2 \mathrm{cc}$ of media in a Bio-Rad ${ }^{\circledR}$ Poly-Prep chromatography column $(0.8 \mathrm{~cm} \times 4 \mathrm{~cm})$. A plutonium solution containing $1.7 \mathrm{E}-6 \mathrm{~g} / \mathrm{L}(\sim 240 \mathrm{DPM} / \mathrm{mL})$ was prepared from a NIST certified reference material (CRM-126) for use in these experiments and is shown in Table 1. A certified $\mathrm{pH} 7$ buffer solution was used to establish the $6.2 \mathrm{pH}$ required for the experiment. The $\mathrm{pH} 7$ buffer consists of monobasic potassium phosphate $\left(\mathrm{KH}_{2} \mathrm{PO}_{4}\right)$ and dibasic sodium phosphate $\left(\mathrm{Na}_{2} \mathrm{HPO}_{4}\right)$. The

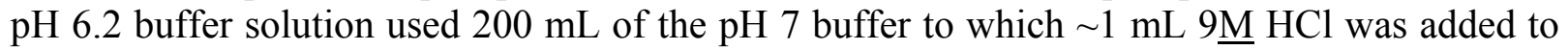
adjust the $\mathrm{pH}$. Fifty milliliters of this $\mathrm{pH} 6.2$ buffer was reserved for the treatment of the media, and $3 \mathrm{~mL}$ of a plutonium standard solution $(1.25 \mathrm{E}+4 \mathrm{DPM} / \mathrm{mL})$ was added to the remaining solution to achieve the desired plutonium concentration. The plutonium tracer solution $\mathrm{pH}$ was adjusted to 6.2 by addition of a few drops of $10 \underline{\mathrm{M}} \mathrm{NaOH}$.

Table 9, CRM-126 Plutonium Standard Data

\begin{tabular}{|c|c|c|c|c|}
\hline ISOTOPE & $\begin{array}{l}\text { HALFLIFE } \\
\text { (years) }\end{array}$ & $\begin{array}{c}N_{0} \\
\text { (wt \%) }\end{array}$ & $\begin{array}{c}\mathrm{N}_{\mathrm{f}}^{*} \\
\text { (wt \%) }\end{array}$ & $\begin{array}{l}\text { TOTAL Pu* } \\
\text { (wt \%) }\end{array}$ \\
\hline $\mathrm{Pu}-238$ & 87.74 & 0.0016 & 0.0013 & \multirow{5}{*}{99.8799} \\
\hline $\mathrm{Pu}-239$ & 24120 & 97.9162 & 97.9306 & \\
\hline $\mathrm{Pu}-240$ & 6562 & 2.0654 & 2.0620 & \\
\hline $\mathrm{Pu}-241$ & 14.35 & 0.0157 & 0.0051 & \\
\hline $\mathrm{Pu}-242$ & 376300 & 0.0010 & 0.0010 & \\
\hline
\end{tabular}

*Decay corrected to 30MAR09

Two $\mathrm{cm}^{3}$ of the selected media was weighed in a tared chromatography column to obtain the dry media weight. The media was conditioned with $10 \mathrm{~mL}$ of $\mathrm{pH} 6.2$ buffer solution and allowed to drain, and a wet media weight obtained. A polypropylene top support (120 $\mu \mathrm{m}$ frit) was placed on top of the resin bed in order to prevent media floatation during the experiments. Media flowrates were determined using $5 \mathrm{~mL}$ of buffer and allowing the eluent to drain completely. The media dry weights, wet weights, void volumes, and flowrates are shown in Table 10.

Table 10, Selected Media Data

\begin{tabular}{|c|c|c|c|c|c|c|}
\hline MEDIA & ID & $\begin{array}{c}\text { DRY } \\
\text { WT } \\
\mathbf{( g )}\end{array}$ & $\begin{array}{c}\text { WET } \\
\mathbf{W T} \\
\mathbf{( g )}\end{array}$ & $\begin{array}{c}\text { VOID } \\
\text { VOLUME } \\
(\mathbf{m L})\end{array}$ & $\begin{array}{c}\text { FLOWRATE } \\
(\mathbf{m L} / \mathbf{m i n})\end{array}$ & TYPE \\
\hline DT-30 & R1 & 1.5732 & 2.2275 & 0.6543 & 3.3 & $\begin{array}{c}\text { Inorganic oxide } \\
300-850 \mu \mathrm{m}\end{array}$ \\
\hline IRN-150 & R2 & 1.2077 & 1.9274 & 0.7197 & 1.2 & $\begin{array}{c}\text { Mixed bed }\left(\mathrm{H}^{+} / \mathrm{OH}^{-}\right) \\
580-700 \mu \mathrm{m}\end{array}$ \\
\hline IRC-748 & R3 & 1.2391 & 2.0409 & 0.8018 & 2.5 & $\begin{array}{c}\text { Chealating Cation } \\
\left(\mathrm{Na}^{+}\right) 500-600 \mu \mathrm{m}\end{array}$ \\
\hline
\end{tabular}


The buffered plutonium tracer solution alpha activity was characterized by liquid scintillation counting (LSC) using a 20-400 keV energy window. The plutonium tracer solution alpha activity was determined to be $238 \mathrm{DPM} / \mathrm{mL} \pm 0.94 \%$ 2-sigma uncertainty. Each media was eluted with $5.00 \mathrm{~mL}$ fractions of this plutonium tracer solution for a total of $40.00 \mathrm{~mL}$ elution volume. Each $5 \mathrm{~mL}$ fraction was mixed with $15 \mathrm{~mL}$ of Ultima Gold LSC cocktail and counted for alpha activity. The LSC counting data and calculated decontamination factor are shown in Tables 11, 12, and 13. The decontamination factor was calculated using the equation (1).

Equation $(1) \quad \mathrm{DF}=(238 \mathrm{DPM} / \mathrm{mL})($ elution volume $\mathrm{mL}) /($ total $\mathrm{DPM})$

Table 11, DT-30 Elution Data @ pH 6.2

\begin{tabular}{|c|c|c|c|c|c|}
\hline ID & $\begin{array}{c}\text { ELUTION } \\
(\mathbf{m L})\end{array}$ & $\begin{array}{c}\text { SAMPLE } \\
(\mathbf{D P M})\end{array}$ & $\begin{array}{c}\mathbf{2 S} \\
\mathbf{( \pm \% )}\end{array}$ & $\begin{array}{c}\text { TOTAL } \\
(\mathbf{D P M})\end{array}$ & $\mathbf{D F}$ \\
\hline R1-1 & $0-5$ & 42.5 & 7.8 & 42.5 & 28 \\
\hline R1-2 & $5-10$ & 53.1 & 6.5 & 95.6 & 25 \\
\hline R1-3 & $10-15$ & 59.6 & 6.0 & 155 & 23 \\
\hline R1-4 & $15-20$ & 72.6 & 5.1 & 228 & 21 \\
\hline R1-5 & $20-25$ & 83.8 & 4.6 & 312 & 19 \\
\hline R1-6 & $25-30$ & 90.0 & 4.4 & 402 & 18 \\
\hline R1-7 & $30-35$ & 94.8 & 4.2 & 496 & 17 \\
\hline R1-8 & $35-40$ & 102 & 4.0 & 598 & 16 \\
\hline
\end{tabular}

Table 12, IRN-150 Elution Data @ pH 6.2

\begin{tabular}{|c|c|c|c|c|c|}
\hline ID & $\begin{array}{c}\text { ELUTION } \\
(\mathbf{m L})\end{array}$ & $\begin{array}{c}\text { SAMPLE } \\
(\mathbf{D P M})\end{array}$ & $\begin{array}{c}\mathbf{2 S} \\
\mathbf{( \mathbf { \% } )}\end{array}$ & $\begin{array}{c}\text { TOTAL } \\
(\mathbf{D P M})\end{array}$ & $\mathbf{D F}$ \\
\hline R2-1 & $0-5$ & 28.8 & 11 & 28.8 & 41 \\
\hline R2-2 & $5-10$ & 44.3 & 7.5 & 73.1 & 33 \\
\hline R2-3 & $10-15$ & 40.9 & 8.0 & 114 & 31 \\
\hline R2-4 & $15-20$ & 143 & 3.2 & 257 & 18 \\
\hline R2-5 & $20-25$ & 173 & 2.8 & 430 & 14 \\
\hline R2-6 & $25-30$ & 182 & 2.7 & 612 & 12 \\
\hline R2-7 & $30-35$ & 190 & 2.7 & 802 & 10 \\
\hline R2-8 & $35-40$ & 197 & 2.6 & 999 & 9.5 \\
\hline
\end{tabular}

Table 13, IRC-748 Elution Data @ pH 6.2

\begin{tabular}{|c|c|c|c|c|c|}
\hline ID & $\begin{array}{c}\text { ELUTION } \\
(\mathrm{mL})\end{array}$ & $\begin{array}{l}\text { SAMPLE } \\
\text { (DPM) }\end{array}$ & $\begin{array}{c}2 \mathrm{~S} \\
( \pm \%)\end{array}$ & $\begin{array}{l}\text { TOTAL } \\
\text { (DPM) }\end{array}$ & DF \\
\hline R3-1 & $0-5$ & 532 & 1.5 & 532 & 2.2 \\
\hline R3-2 & $5-10$ & 619 & 1.3 & 1151 & 2.1 \\
\hline R3-3 & $10-15$ & 606 & 1.4 & 1757 & 2.0 \\
\hline R3-4 & $15-20$ & 637 & 1.3 & 2394 & 2.0 \\
\hline R3-5 & $20-25$ & 614 & 1.3 & 3008 & 2.0 \\
\hline R3-6 & $25-30$ & 453 & 1.6 & 3461 & 2.1 \\
\hline R3-7 & $30-35$ & 351 & 1.8 & 3812 & 2.2 \\
\hline R3-8 & $35-40$ & 318 & 2.0 & 4130 & 2.3 \\
\hline
\end{tabular}


The above LSC counting data shows that the DT-30 media possessed the highest stable decontamination factor (16), followed by IRN-150 (10), and IRC-748 (2.3). This would indicate the removal of $94 \%, 89 \%$, and $57 \%$ of plutonium activity by the respective media during the $40 \mathrm{~mL}$ elutions. The trend of decreasing retention of the plutonium on the media generally shows a possible saturation of the media over the test. The Free Column Volume (FCV) of each media tested can be calculated from the difference in dry and wet media weights or void volume. A summary of the media decontamination factors, plutonium removal, FCV, and total FCV's for the $40 \mathrm{~mL}$ elutions are summarized for comparison in Table 14.

Table 14, Media Df and Elution Results

\begin{tabular}{|c|c|c|c|c|}
\hline MEDIA & Df & $\begin{array}{c}\text { Pu REMOVAL } \\
\text { (\%) }\end{array}$ & $\begin{array}{c}\text { FCV } \\
\text { (mL) }\end{array}$ & FCV's ELUTED \\
\hline DT-30 & 16 & 94 & 0.65 & 61 \\
\hline IRN-150 & 10 & 89 & 0.72 & 55 \\
\hline IRC-748 & 2.3 & 57 & 0.80 & 50 \\
\hline
\end{tabular}

From the elution data collected, a dynamic distribution coefficient $\left(\mathrm{K}_{\mathrm{D}}\right)$ can be determined for plutonium and the selected media at $\mathrm{pH}$ 6.2. This dynamic $\mathrm{K}_{\mathrm{D}}$ is a better approximation of media characteristics for the removal of plutonium in a flow-through column system that will be scaled up for further testing. The calculation of this dynamic distribution coefficient is shown in equation (2).

Equation (2)

$$
\begin{aligned}
& \mathrm{K}_{\mathrm{D}}=\left(\mathrm{Pu}_{\text {media }} / \mathrm{g}_{\text {media }}\right) /\left(\mathrm{Pu}_{\text {solute }} / \mathrm{mL}_{\text {solute }}\right) \\
& \mathrm{Pu}_{\text {media }}=\mathrm{Pu} \text { activity loaded }-\mathrm{Pu} \text { activity recovered }(\mathrm{DPM}) \\
& \mathrm{g}_{\text {media }}=\text { wet media weight }(\mathrm{g}) \\
& \mathrm{Pu}_{\text {solute }}=\mathrm{Pu} \text { activity recovered }(\mathrm{DPM}) \\
& \mathrm{mL}_{\text {solute }}=40 \mathrm{~mL}
\end{aligned}
$$

Table 15 below shows the data used for the calculation of the dynamic distribution coefficient for plutonium on the selected media.

Table 15, Dynamic Distribution Coefficient at pH 6.2

\begin{tabular}{|c|c|c|c|c|c|}
\hline MEDIA & $\begin{array}{c}\text { Pu } \\
\text { LOADED } \\
\text { (DPM) }\end{array}$ & $\begin{array}{c}\text { RECOVERED } \\
\text { (DPM) }\end{array}$ & $\begin{array}{c}\text { MEDIA } \\
\text { ACTIVITY } \\
\text { (DPM) }\end{array}$ & $\begin{array}{c}\text { WET } \\
\text { WEIGHT } \\
\text { (g) }\end{array}$ & $\begin{array}{c}\mathbf{K}_{\mathbf{D}} \\
\text { (mL/g) }\end{array}$ \\
\hline DT-30 & 9504 & 598 & 8906 & 2.2275 & 267 \\
\hline IRN-150 & 9504 & 999 & 8505 & 1.9274 & 177 \\
\hline IRC-748 & 9504 & 4130 & 5374 & 2.0409 & 26 \\
\hline
\end{tabular}

The dynamic distribution coefficients for plutonium at $\mathrm{pH} 6.2$ agree with the media decontamination factors obtained in the previous tests. The sample contact time is longer (lower flow velocity) for these small scale tests when compared to the pilot scale system testing using a $2.5 \mathrm{~cm}$ diameter column. A comparison of the small scale tests flow rates and fluid velocities to that of the proposed IX system test are shown in Table 16. 
TABLE 16, Comparison of Small Scale to Pilot Scale System Flows.

\begin{tabular}{|c|c|c|c|c|}
\hline MEDIA & $\begin{array}{c}\text { FLOW RATE* } \\
\text { (mL/min) }\end{array}$ & $\begin{array}{c}\text { VELOCITY* } \\
\text { (cm/min) }\end{array}$ & $\begin{array}{c}\text { FLOW RATE** } \\
\text { (mL/min) }\end{array}$ & $\begin{array}{c}\text { VELOCITY** } \\
\text { (cm/min) }\end{array}$ \\
\hline DT-30 & 3.3 & 6.6 & 283 & 56 \\
\hline IRN-150 & 1.2 & 2.4 & 377 & 74 \\
\hline IRC-748 & 2.5 & 5.1 & 472 & 93 \\
\hline
\end{tabular}

*Small scale tests with $0.8 \mathrm{~cm}$ diameter $\mathrm{x} 4 \mathrm{~cm}$ column and gravity flow.

**IX system proposed flowrates with 1 in diameter x 24 in column and forced flow.

\subsection{Pilot Scale Tests of Ion-Exchange Media}

The overall series of tests performed for this project were designed to support each other and show consistency in the overall results. To integrate this phased approach the tests were designed to build upon each other. We started with the initial "static" tests (determining the $\mathrm{K}_{\mathrm{D}}$ ) went to characterization of plutonium oxide in water, dynamic small column tests and finally the pilot scale tests using a system similar to that found in the field. A photograph of the pilot system is shown in Figure 4.

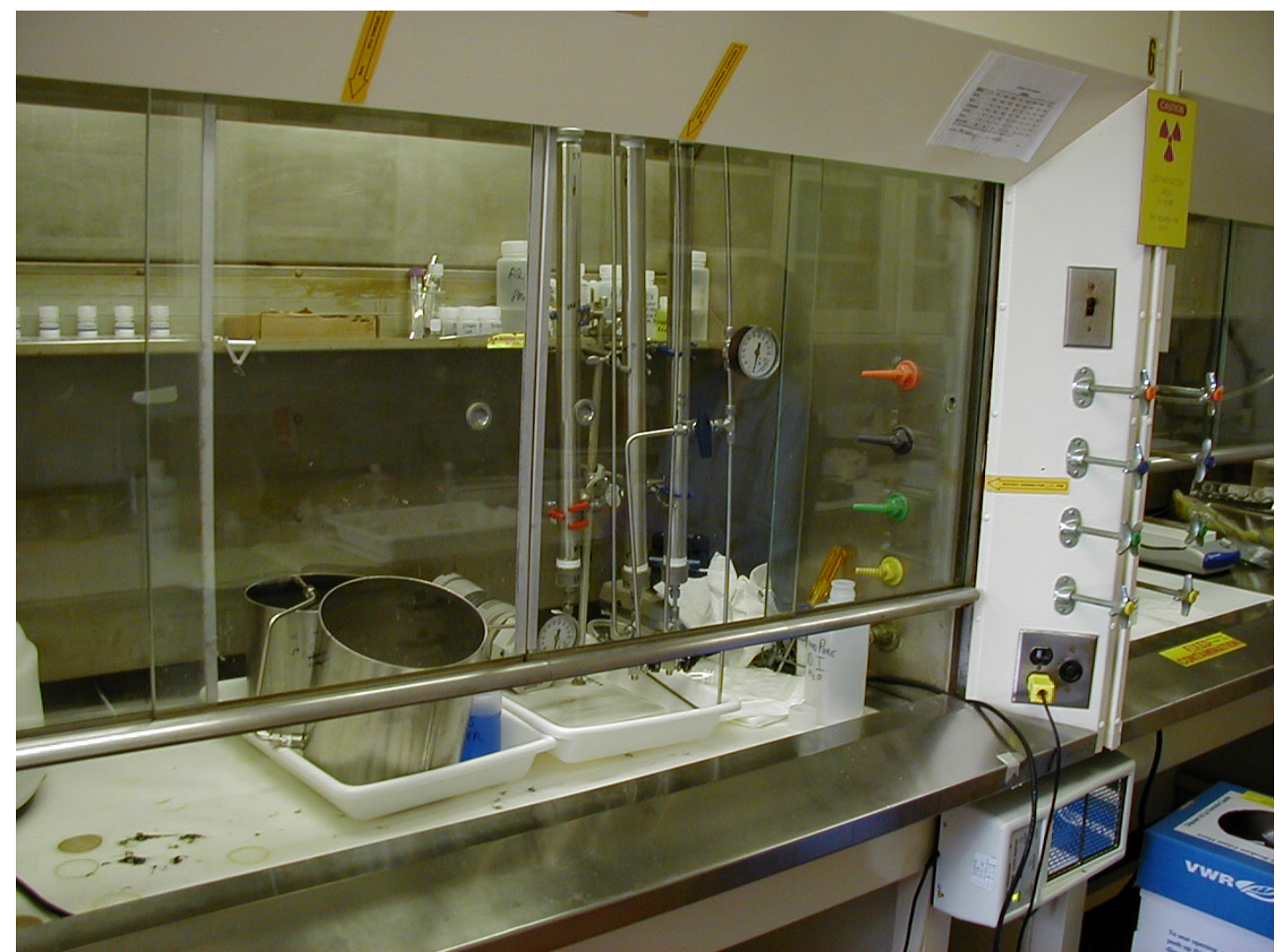

Figure 4, Photograph of IX system ( ${ }^{\text {st }}$ test cleanup with effluent vessel disconnected)

The pilot scale tests were performed, using flows and equipment that mimic those found in basin water treatment systems. Three columns were arranged to simulate a water treatment system, but instead of using hundreds of cubic feet of resin each, each column contained approximately 0.01 cubic feet (2' long and 1" diameter) or 294 milliliters. The system was 
constructed of stainless steel and used a peristaltic pump to pass 3 liters of plutonium contaminated solution through the columns. Polyethylene, polypropylene or stainless steel was used throughout the system (with the plastic used only in the peristaltic pump tubing and the secondary frit on the bottom of the columns); this reduced the likelihood of plating of the plutonium, known to occur on glass and Teflon. This system schematic is shown in Figure 5.

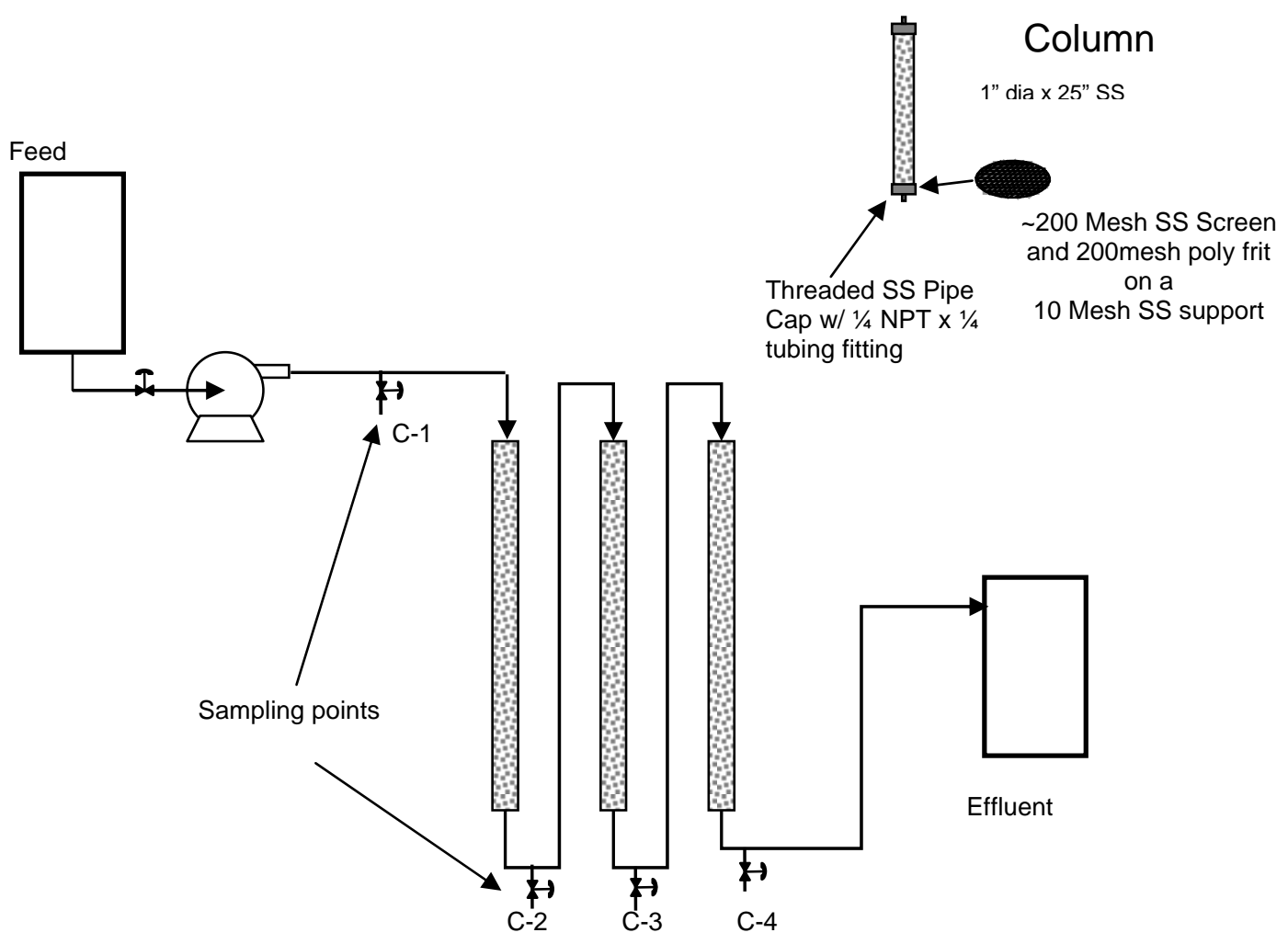

Figure 5, Schematic of Final IX System

The flow of the pilot system was scaled to simulate that used in a system. The full system flows would be $22.0,29.3$ and $36.7 \mathrm{in.} . / \mathrm{min} . / \mathrm{in}^{2}$, which were simulated for these tests (proportional to the size of the columns) as $283 \mathrm{ml} / \mathrm{min}, 377 \mathrm{ml} /$ and $472 \mathrm{ml} / \mathrm{min}$. Flow tests were performed (with consistent results) prior to Test 1 and Test 2 and the pump setting (and pressure) were set after these tests. That flow data is given in Table 16. The tests were set to pump at the designated flow for two minutes then the effluent of the each column was sampled (the feed was also sampled at the inlet to the first column, but consistent results were not obtained at this sampling point). While sample results consistent with the expected values were obtained from the feed vessels, they were not obtained from valve $\mathrm{C}-1$. In one case this was known to be from a heel in the sampling line, and it is suspected that the pulsed flow nature of the peristaltic pump contributes to the inconsistency. At the end of each test the effluent was sampled in the effluent vessel. 
Table 16, Pump Setting, Pressure and Flow

\begin{tabular}{|c|c|c|}
\hline Pump setting & $\begin{array}{l}\text { Pressure } \\
\text { (psi) }\end{array}$ & Flow (ml/min) \\
\hline \multicolumn{3}{|l|}{ Test 1, 3 columns (IRN-150, DT-30, IRN-150) } \\
\hline 2 & 14 & 225 \\
\hline 3 & 24 & 340 \\
\hline 4 & 25 & 434 \\
\hline 5 & 28 & 600 \\
\hline \multicolumn{3}{|l|}{ Test 2, 1 column (IRC-748) } \\
\hline 1 & 1 & 122 \\
\hline 2 & 5 & 240 \\
\hline 3 & 7 & 375 \\
\hline 4 & 10 & 500 \\
\hline 5 & 15 & 750 \\
\hline
\end{tabular}

The columns were loaded with a slurry of the individual media. The columns had a large stainless steel screen (50 mesh) support inserted in the bottom, with a 200 mesh stainless screen on top of that, and a polypropylene frit on that. The column bottom was fitted to the column and the slurry was added. The slurry was typically about a $50 \%$ water mixture, which at times required more or less water to flow into the top of the column. Excess water flowed out of the bottom of the column while the media settled. When the slurry was close to the top of the column and the water ceased flowing from the bottom, the cap piece was placed on the column. The columns were placed in order as previously determined by test 1 or 2 (see table 16 above for order of resin in the tests). Full flow tests using water at pressures up to 60 psi confirmed that the system was leak free and ready for radioactive tests. A few leaks were located in the first assembly, but were quickly dispatched. For safety reasons, the system was pressure tested with water a total of five times.

The simulant for the test was composed of a decanted portion of a water/plutonium oxide $\left(\mathrm{PuO}_{2}\right)$ mixture (detailed in section II as $\mathrm{PuO} 2 \mathrm{\# 1}$ ). The plutonium oxide was mixed with the water in early April and allowed to sit (undisturbed) for about 3 weeks. This solution had been tested several times and the results are described in section II. About $50 \mathrm{ml}$ of the solution was decanted away from the solids to be used for these tests. Though no consistent analysis of this solution could be obtained, LSC analysis indicated that this solution should be about 60,000 $\mathrm{DPM} / \mathrm{ml}$. The decanted solution was well mixed and a $20 \mathrm{ml}$ aliquot was added to 2.5 liters of high resistivity water as feed for Test 1 . The final makeup and mixing took place in the feed tank of the system. The solution $\mathrm{pH}$ was tested and found to be 6.2. This solution was then sampled and ready for use in the system. Test 2 was essentially the same, but a $25 \mathrm{ml}$ aliquot was added to a 3 liter makeup.

The actual tests were performed very quickly and easily compared with preparation, analysis of the feedstock (checked and rechecked over several weeks) and safety review of the system. Since consistent analysis results of the feedstock could not be reasonably obtained, we tried to overshoot the concentration of the feedstock for best results (actually only about a factor of 2). The results of the feed and also of the individual analyses for each sample are shown on Table 17. Both with Test 1 and Test 2 took only about 10-15 minutes. Preparation of the columns, 
feedstock, removing the media and refilling the columns took about 3 weeks. The concentration in $\mathrm{ug} / \mathrm{l}$ is calculated based on the specific activity of ${ }^{239} \mathrm{Pu}$ and the measured activity of the sample.

Samples of the effluents from each column were also removed during the tests and analyzed by LSC. About a $25 \mathrm{ml}$ sample was removed from each valve below the column during each flow regime. During the tests the flow was established for 2 minutes and then the sampling was performed (typically about 1 minute for sampling). The sample results are shown on Table 17 by column $(1,2$, etc) and the flow $(283$, etc). A $5 \mathrm{ml}$ sample of each solution was analyzed by LSC.

The pilot scale test results were very consistent with those found in earlier tests and showed a regular pattern in the data. These results are compared in Table 17. In Test 1 no real contamination was found in solutions beyond the first column of IRN-150 (Column 1). One sample result, during the second flow series, showed slight contamination out of column 1, but the results were at background levels. No plutonium contamination was found in the system effluent. By contrast, in Test 2 (using one column of IRC-748, Column 4) substantial levels of plutonium contamination were found in each sample of the effluent. Contamination was also found in the media from columns 1 and 4, showing that these columns were removing plutonium from the water, but no contamination was found in media from columns 2 and 3 , probably because column 1 had been highly effective. Calculated effectiveness for the two systems (Test 1 and Test 2 ) overall were $>99 \%$ and $80 \%$ respectively. While all the samples in Test 1 showed $>99 \%$ removal, those in Test 2 showed between $55 \%$ and $80 \%$ removal throughout the test with the lower removal occurring early in the test. 
Table 17, Analysis Results for Pilot Scale Samples.

\begin{tabular}{|c|c|c|c|c|c|}
\hline Sample location/name & $\begin{array}{l}\text { LSC result } \\
(\mathrm{dpm} / 5 \mathrm{ml})\end{array}$ & $\%$ Error & Spl Date & uCill & ug/l \\
\hline $\begin{array}{l}50 \mathrm{ml} \text { concentrated makeup } \\
(\mathrm{dpm} / \mathrm{ml})\end{array}$ & 60,000 & * & $4 / 22 / 2009$ & 27.27 & 439.2 \\
\hline \multicolumn{6}{|l|}{ TEST 1 (Set A) } \\
\hline Pu water, in Feed vessel & 1689.97 & 0.64 & $4 / 23 / 2009$ & 0.154 & 2.474 \\
\hline column 1 effluent $283 \mathrm{ml} / \mathrm{min}$ & 0 & 0 & $4 / 23 / 2009$ & 0 & 0 \\
\hline column 2 effluent $283 \mathrm{ml} / \mathrm{min}$ & 0 & 0 & $4 / 23 / 2009$ & 0 & 0 \\
\hline column 3 effluent $283 \mathrm{ml} / \mathrm{min}$ & 0 & 0 & $4 / 23 / 2009$ & 0 & 0 \\
\hline column 1 effluent $377 \mathrm{ml} / \mathrm{min}$ & 6.38 & 32.26 & $4 / 23 / 2009$ & $6 \mathrm{E}-04$ & 0.009 \\
\hline column 2 effluent $377 \mathrm{ml} / \mathrm{min}$ & 0 & 0 & $4 / 23 / 2009$ & 0 & 0 \\
\hline column 3 effluent $377 \mathrm{ml} / \mathrm{min}$ & 0 & 0 & $4 / 23 / 2009$ & 0 & 0 \\
\hline Feed $472 \mathrm{ml} / \mathrm{min}$ (valve at C-1) & 565.72 & 1.14 & $4 / 23 / 2009$ & 0.051 & 0.828 \\
\hline column 1 efluent $472 \mathrm{ml} / \mathrm{min}$ & 0 & 0 & $4 / 23 / 2009$ & 0 & 0 \\
\hline column 2 efluent $472 \mathrm{ml} / \mathrm{min}$ & 0 & 0 & 4/23/2009 & 0 & 0 \\
\hline column 3 efluent $472 \mathrm{ml} / \mathrm{min}$ & 0 & 0 & $4 / 23 / 2009$ & 0 & 0 \\
\hline Test 1 effluent in receiver & 0 & 0 & $4 / 29 / 2009$ & 0 & 0 \\
\hline Acid flush from Test 1 & 0 & 0 & $4 / 30 / 2009$ & 0 & 0 \\
\hline \multicolumn{6}{|l|}{ TEST 2 (Set B) } \\
\hline Pu water, in Feed vessel & 1485.47 & 0.68 & $4 / 29 / 2009$ & 0.135 & 2.175 \\
\hline Feed $283 \mathrm{ml} / \mathrm{min}$ (valve at C-1) & 1274.65 & 0.74 & $4 / 29 / 2009$ & 0.116 & 1.866 \\
\hline column 4 effluent $283 \mathrm{ml} / \mathrm{min}$ & 498.2 & 1.22 & $4 / 29 / 2009$ & 0.045 & 0.729 \\
\hline column 4 effluent $377 \mathrm{ml} / \mathrm{min}$ & 693.73 & 1.02 & $4 / 29 / 2009$ & 0.063 & 1.016 \\
\hline Feed $472 \mathrm{ml} / \mathrm{min}$ (valve at C-1) & 811.38 & 0.94 & $4 / 29 / 2009$ & 0.074 & 1.188 \\
\hline column 4 effluent $472 \mathrm{ml} / \mathrm{min}$ & 342.55 & 1.5 & $4 / 29 / 2009$ & 0.031 & 0.501 \\
\hline Test 2 effluent in receiver & 300.98 & 1.62 & $4 / 29 / 2009$ & 0.027 & 0.441 \\
\hline \multicolumn{6}{|l|}{ (solid media samples) } \\
\hline & $(\mathrm{dpm} / \mathrm{g})$ & & & uCi/kg & ug/kg \\
\hline column 1 resin & 1903.3 & 0.6 & $4 / 29 / 2009$ & 0.865 & 13.93 \\
\hline Column 1 resin $1 \mathrm{st} \mathrm{cm}$. & 2044.02 & 0.58 & $4 / 29 / 2009$ & 0.929 & 14.96 \\
\hline column 2 resin & 0 & 0 & $4 / 29 / 2009$ & 0 & 0 \\
\hline column 3 resin & 0 & 0 & $4 / 29 / 2009$ & 0 & 0 \\
\hline column 4 resin & 909.83 & 0.88 & $4 / 30 / 2009$ & 0.414 & 6.66 \\
\hline
\end{tabular}




\section{RESULTS DISCUSSION AND EVALUATION}

The results of these tests consistently demonstrated that the issues of plutonium contamination from an oxide form dissolved or suspended in water are real and difficult, and also that a properly designed ion-exchange system may remove the contamination from the water. The results from the "bench scale" $\mathrm{K}_{\mathrm{D}}$ and dynamic flow tests were very consistent and showed that the highest removal efficiency was achieved from the DT-30 (94\%) with the IRN-150 next $(89 \%)$ and with the lowest efficiency with IRC-748 (57\%). The "pilot scale" tests showed that the IRN-150 (first column) had even higher efficiency with $>99 \%$ removal (virtually $100 \%$ ) in each of the 3 flow regimes; this was consistent with the results of the "bench scale" tests. The "pilot scale" tests also showed that the IRC-748 was less effective, but at $80 \%$ overall effectiveness, it was substantially higher than the "bench scale" tests. This testing, both the bench and pilot scales, confirmed that effective removal of the plutonium can be achieved. This was also proof that the early "bench scale" tests, using a fully dissolved (acidic) plutonium standard neutralized to $\mathrm{pH} 6.2$ behaved very similar to the supernatant of a plutonium oxide/water mixture but with better homogeneity.

During this project we also found some interesting characteristics of plutonium oxide/water mixtures. This is likely due to the presence of colloidal or other species that are not truly dissolved but never-the-less contribute to the plutonium concentration in the water at any given time. These heterogeneous species make it very difficult to accurately determine the concentration and may cause significant difficulty in measurements in the field. 